ORIGINAL ARTICLE

\title{
Preliminary results of using green manure species as a cost- effective option for forest restoration
}

\author{
Resultados preliminares da utilização de adubo verde como uma opção custo- \\ benefício para a restauração florestal
}

\author{
Diana Carolina Vásquez-Castro ${ }^{1,2}$ (D) Ricardo Ribeiro Rodrigues $^{3}$ (D), Paula Meli ${ }^{1,4}$ (D), \\ Pedro Henrique Santin Brancalion ${ }^{1}$ ] , Renato Rodrigues Silva ${ }^{5}$ (1) , Hilton Thadeu Zaratedo Couto ${ }^{1}$ USP, Piracicaba, SP, Brasil
2Universidad de la Amazonia - UDLA, Florencia, Colombia
3Departamento de Ciências Biológicas, Escola Superior de Agricultura "Luiz de Queiroz" - ESALQ, Universidade de São Paulo - USP, Piracicaba, SP, Brasil
${ }^{4}$ Departamento de Ciencias Forestales, Universidad de La Frontera, Temuco, Chile \\ 1Departamento de Ciências Florestais, Escola Superior de Agricultura "Luiz de Queiroz" - ESALQ, Universidade de São Paulo - \\ IInstituto de Matemática e Estatística, Universidade Federal de Goiás - UFG, Goiânia, GO, Brasil
}

\begin{abstract}
How to cite: Vásquez-Castro, D. C. V., Rodrigues, R. R., Meli, P., Brancalion, P. H. S., Silva, R. R., \& Couto, H. T. Z. (2020). Preliminary results of using green manure species as a cost-effective option for forest restoration. Scientia Forestalis, 48(127), e3374. https://doi.org/10.18671/scifor.v48n127.21
\end{abstract}

\begin{abstract}
Reducing costs of implementation and maintenance of restoration activities is crucial for a project's success. In order to achieve it, direct seeding and the use of green manure species have been proposed as potential alternatives. Here, we compare some preliminary results on seedlings performance and cost on four restoration techniques including these alternatives in the Atlantic Forest of Brazil. In 16 plots, we established: (1) conventional seedling planting of 20 native species ( $2 \times 3 \mathrm{~m}$ spacing between plants), (2) direct seeding of Senna alata among the seedlings of the 20 native species; (3) direct seeding of Cajanus cajan among seedlings of the 20 native species and; (4) direct seeding of Leucaena leucocephala in the inter-row of the 20 native species seedlings. A year later seedling performance (survival and growth) resulted similar among these four techniques. However, costs of using Senna and Cajanus were consistently lower, mainly during the maintenance phase due to the reduction of fertilization and individual protection needs. Introducing green manure species by direct seeding may be a useful strategy to complement and eventually replace planting seedlings of other high-growth rate species to rapidly cover the soil surface. This approach may partially reduce some financial costs, particularly at the early stages of projects. Other strategies should be evaluated to complement our results.
\end{abstract}

Keywords: Direct seeding; Covering species; Restoration cost.

\section{Resumo}

Reduzir os custos de implantação e manutenção de atividades de restauração é uma importante ação para o sucesso do projeto. A semeadura direta e o uso de espécies de adubação verde têm sido propostas como possíveis alternativas para isso. No presente trabalho, comparamos os resultados e o custo de quatro técnicas de restauração incluindo essas alternativas dentro da Mata Atlântica do Brasil.Em 16 parcelas, estabelecemos: (1) mudas de plantio convencionais de 20 espécies nativas (espaçamentos de $2 \times 3 \mathrm{~m}$ ), (2) semeadura direta de Senna alata entre as mudas das 20 espécies nativas; (3) semeadura direta de Cajanus cajan entre mudas das 20 espécies nativas e; (4) semeadura direta de Leucaena leucocephala na entrelinha das 20 mudas de espécies nativas.Após um ano, o desempenho das plântulas (sobrevivência e crescimento) foi similar nas quatro técnicas. No entanto, os custos de uso de Senna e Cajanus foram consistentemente menores, principalmente durante a fase de manutenção,

Financial support: PEC-PG CNPq (Scholarship 190577/2010-0), CNPq (Project 561897/2010-7), FAPESP (2013/50718-5) and FONDECYT (Project 11191021).

Conflict of interest: Nothing to declare.

Corresponding author: dianavasquez@alumni.usp.br

Received: 10 May 2019.

Accepted: 15 October 2019.

Editor: Paulo Henrique Müller Silva. (c) This is an Open Access article distributed under the terms of the Creative Commons Attribution License, which permits unrestricted use,
distribution, and reproduction in any medium, provided the original work is properly cited. 
devido à redução das necessidades de fertilização e proteção individual.A introdução de espécies de adubo verde por semeadura direta pode ser uma estratégia útil para complementar e, eventualmente, substituir o plantio de mudas de outras espécies de alta taxa de crescimento para cobrir rapidamente a superfície do solo. Essa abordagem pode diminuir parcialmente alguns custos financeiros, particularmente nos estágios iniciais de projetos. Outras estratégias devem ser avaliadas para complementar nossos resultados.

Palavras-chave: Semeadura direta; Cobertura de espécies; Custo de restauração.

\section{INTRODUCTION}

Current international policies aimed at ecosystem restoration have received global attebtion in recent years (Jørgensen, 2015), especially in tropical regions (Palma \& Laurance, 2015). In this context, it is imperative that ecological restoration provides cost-effective solutions (Kimball et al., 2015), as costs have become an obstacle for the proper development of a restoration project (De Groot et al., 2013). In order to reduce the high restoration costs of total planting seedlings, direct seeding has been proposed as a promising alternative strategy for restorationin in several ecosystems (Ceccon et al., 2016; Grossnickle \& Ivetić, 2017; Meli et al., 2018). However, it is still necessary to adjust these methodologies and also combine them with other methods.

The use of green manure species such as shrub legumes combined with planting seedlings of various species is a relevant methodological alternative in ecological restoration (Campos-Filho et al., 2013; Silva et al., 2015). The main reasons are because it contributes to the fixation of biological nitrogen through th e symbiosis of bacteria, it improves soil quality, it increases protein for animal feed, and it helps to control pastures (César et al., 2013). Besides all that, it is also an opportunity to educe operational costs (Rodrigues et al., 2009a). Some leguminous species with high grow rates and high density of seed production may contribute to the initial processes of restoration of degraded areas (Viani et al., 2015). For instance, introducing the "guandu" bean (Cajanus cajan), a shrubby bean frequently used in Brazil for food and green manure, mixed with forest tree seedlings, may increase tree survival and growth, compared to the single planting of the tres (Beltrame \& Rodrigues, 2007). These species are semi-perennial woody species that fix nitrogen and are important for the first stages of the restoration process, as they substitute other species used to promote soil coverage by vegetation. Among these species, despite being exotic, Leucaena leucocephala has been suggested as a useful species due to its capacity of controlling grass growth (Uribe et al., 2011). Here, we present preliminary results on the establishment of seedlings of native species and the costs of the implantation and maintenance of four restoration techniques in abandoned sugarcane fields in the Atlantic Forest in Brazil. Our main goals are: (1) compare survival and growth of the seedlings' community under four different restoration techniques and, (2) compare the economic costs of these four techniques.

\section{MATERIALS AND METHODS}

We selected two former sugarcane plantations, which were abandoned 60 years ago, in São Paulo state. Both sites are in a mesothermal climate with dry winter (Cwa) (Nave et al., 2009) and constitute a typical seasonal semi-deciduous forest. For this study, seeds of three legume species were selected for covering and green manure: an exotic commercial species used as green manure of the Cajanus cajan variety "BRS Mandarin", developed by Embrapa Sudeste São Carlos, SP; Leucaena leucocephala; and one species of regional occurrence in the remaining forests of the región: Senna alata. Two of the species chosen: Cajanus cajan" BRS Mandarin" and Senna alata, are shrubs, nitrogen fixing and of semi-perennial life cycle. Because it is considered important in the initial phase in the restoration plantations (Rodrigues et al., 2009b), and as auxiliary technique for the control of competing species, Leucaena leucocephala was also used in the experiment.

Four experimental blocks $(96 \times 30 \mathrm{~m})$ were established at each location. Each block was composed of four plots $(24 \times 30 \mathrm{~m}$ each, 16 plots in total per location, as shown in Figure $1 \mathrm{~A}$ and 
Figure 1B). Each plot was randomly assigned to one of four treatments, namely: (1) conventional tree planting of 20 native seedling species, i.e., $2 \times 3 \mathrm{~m}$ spacing plants, as shown in Table 1 and details in Rodrigues et al. (2009a); (2) direct seeding of Senna alata among the seedlings of the 20 native species; (3) direct seeding of Cajanus cajan among seedlings of the 20 native species and; (4) direct seeding of Leucaena leucocephalain the inter-row of the 20 native species seedlings. Plot 4 was designed to test the strategy for minimizing weed presence between rows, in order to decrease weed control costs and promote development of cover and diversity of species in the recovery of degraded areas as well as a posible for cattle feed. These three species are considered important for the initial phase of restoration plantings (Rodrigues et al., 2011). Seeds were sown at 2-3in depth.

Table 1. The 20 native seedling species introduced in the restoration plots.

\begin{tabular}{|c|c|}
\hline Scientific name & Family \\
\hline Myracrodruon urundeuva Allemão & Anacardiaceae \\
\hline \multicolumn{2}{|l|}{ Tapirira guianensis Aubl. } \\
\hline Syagrus romanzoffiana (Cham.) Glassman & Arecaceae \\
\hline Tabebuia chrysotricha (Mart. ex A. DC.) Standl. & Bignoniaceae \\
\hline \multicolumn{2}{|l|}{ Tabebuia impetiginosa (Mart. ex DC.) Standl. } \\
\hline Cordia superba Cham. & Boraginaceae \\
\hline \multicolumn{2}{|l|}{ Cordia trichotoma (Vell.) Arráb. ex Steud. } \\
\hline Cecropia pachystachya Trécul & Cecropiaceae \\
\hline Copaifera langsdorffii Desf. & Fabaceae \\
\hline \multicolumn{2}{|l|}{ Myroxylon peruiferum L. f. } \\
\hline Vitex montevidensis Cham. & Lamiaceae \\
\hline Cariniana estrellensis (Raddi) Kuntze & Lecythidaceae \\
\hline Lafoensia pacari A. St.-Hil. & Lythraceae \\
\hline Cedrela fissilis Vell. & Meliaceae \\
\hline Eugenia uniflora L. & Myrtaceae \\
\hline Rhamnidium elaeocarpum Reissek & Rhamnaceae \\
\hline Casearia gossypiosperma Briq. & Salicaceae \\
\hline Allophylus edulis var. gracilis Radlk & Sapindaceae \\
\hline Diatenopteryx sorbifolia Radlk. & Sapindaceae \\
\hline Citharexyllum myrianthum & Verbenaceae \\
\hline
\end{tabular}

One year after planting we evaluated survival and growth (height and diameter) of the 20 native species seedlings, as well as grass and canopy cover. Grass cover was measured in three $2 \times 3 \mathrm{~m}$ subplots in each plot. Canopy cover was estimated by measuring the maximum and minimum canopy diameters for each individual tree in each plot. Considering that we implemented the restoration techniques in two different areas, we carried out the data analysis of variance (ANOVA) in a randomized complete block model in the Statistical Analysis System.

Cost analysis was estimated by comparing the economical expenses on inputs (e.g. fertilizers, plants, labor) and activities (e.g. planting, control of grasses) needed for each restoration strategy. The study was carried out in 2013 and all prices and costs were reported by their current values in dollars for that year and by hectare. All values were obtained by oral communication (BIOFLORA-Técnologia de Restauração, 2013). 

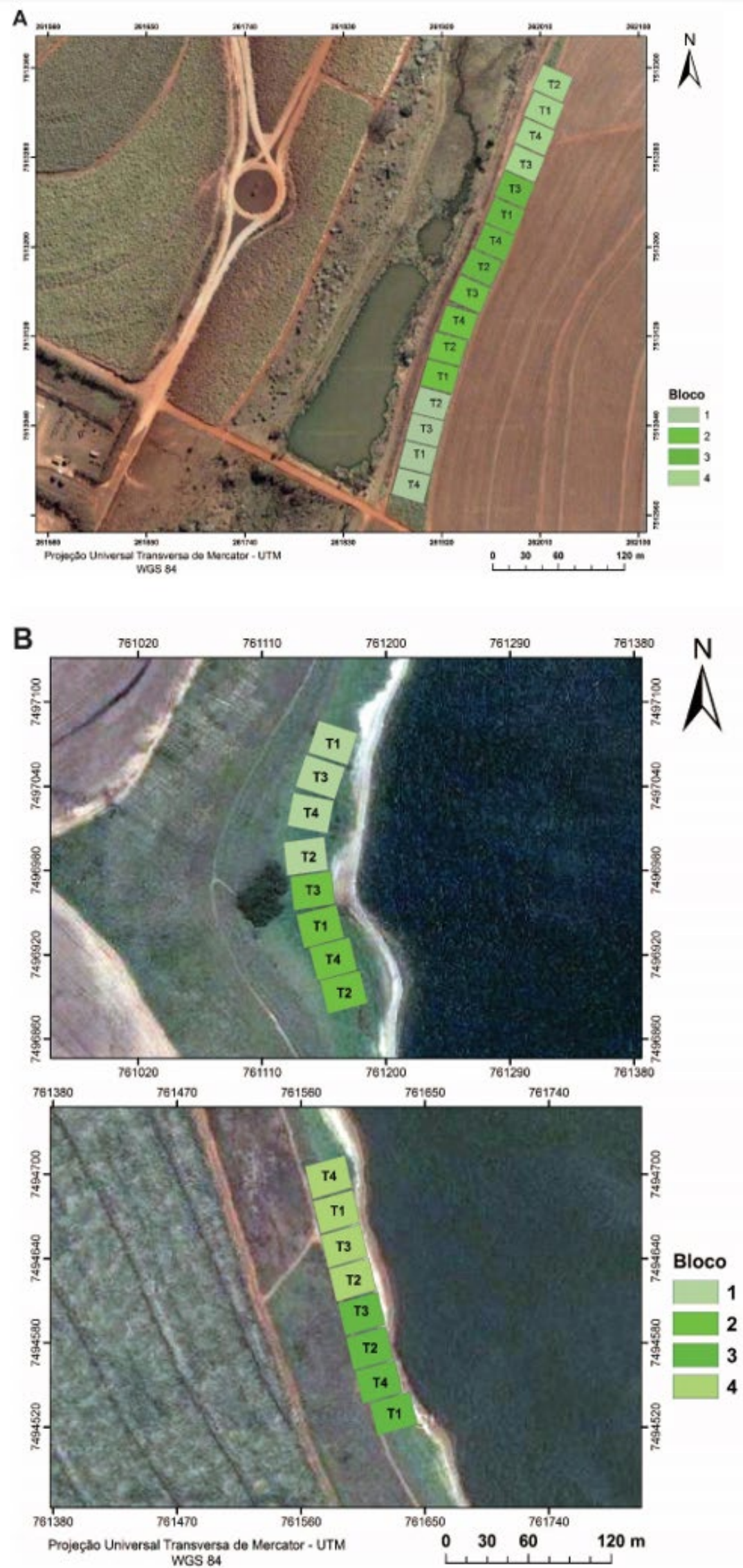

Figure 1. Distribution of experimental plots in São João $(A)$ and São Manoel $(B)$ plants. The rectangle represents the experimental area, each area comprises four blocks of four plots each. 


\section{RESULTS AND DISCUSSION}

Seedlings' survival and growth, as well as grass and canopy cover, were similar among treatments (Table 2), suggesting that there is no ecological benefit for using one or other restoration strategy. However, total costs were $50 \%$ lower when using both Senna and Cajanus than when using conventional activities (using or not Leucaena; Figure 1), while planting Leucaena in the inter-row of the native seedlings implied only in a $6 \%$ reduction of the total cost from using the conventional strategy. These variations in costs were different depending on the project phase. During the implementation phase, using Senna and Cajanus resulted in a $25 \%$ reduction compared to the conventional strategy since it is not necessary to replant seedlings, while planting Leucaena generates a $17 \%$ increase in the cost. However, during the maintenance phase, the reduction of fertilization and individual protection needs when using Senna and Cajanus resulted in an 80\%-decrease in the total cost. Planting Leucaena reduced weed control and fertilizing costs by $14 \%$.

Table 2. Results of randomized complete block analyses of variance on survival, stem diameter and height of native seedlings introduced, canopy cover, and grass cover in 16 restoration plots in two study sites of the Atlantic Forest in Brazil.

\begin{tabular}{cccccccccccc} 
& \multicolumn{2}{c}{ Survival } & \multicolumn{2}{c}{ Diameter } & \multicolumn{2}{c}{ Height } & \multicolumn{2}{c}{ Canopy cover } & \multicolumn{2}{c}{ Grass cover } \\
& F & $\begin{array}{c}\text { P } \\
\text { value }\end{array}$ & $\mathbf{F}$ & $\begin{array}{c}\mathbf{P} \\
\text { value }\end{array}$ & $\mathbf{F}$ & $\begin{array}{c}\mathbf{P} \\
\text { value }\end{array}$ & $\mathbf{F}$ & $\begin{array}{c}\mathbf{P} \\
\text { value }\end{array}$ & $\mathbf{F}$ & $\begin{array}{c}\mathbf{P} \\
\text { value }\end{array}$ \\
\hline Site & 16.84 & 0.0007 & 61.31 & $<0.001$ & 27.86 & $<0.001$ & 42.94 & $<0.001$ & 3883.1 & $<0.001$ \\
Block & 2.14 & 0.1307 & 0.55 & 0.6517 & 0.73 & 0.5494 & 3.96 & 0.0249 & 1.37 & 0.2849 \\
SitexBlock & 1.07 & 0.3863 & 6.25 & 0.0043 & 4.70 & 0.0136 & 4.53 & 0.0156 & 1.31 & 0.3014 \\
Treatments & 0.29 & 0.8321 & 0.92 & 0.4527 & 0.57 & 0.6434 & 0.11 & 0.9511 & 0.91 & 0.4563 \\
SitexTreatments & 0.27 & 0.8441 & 0.68 & 0.5761 & 0.32 & 0.8077 & 0.88 & 0.4695 & 0.15 & 0.9282 \\
\hline
\end{tabular}

Thus, it can still be said that direct seeding can be combined with the planting of seedlings, either for aggregation or for enrichment of the area (Meli et al., 2018). Leucaena was used with the purpose of aiding the development of seedlings and, consequently, of reducing competing species in the area. Leucaena is an exotic species used all over the world for different economic purposes (Lamprecht, 1990). In Brazil, it has been used in mixed reforestation projects due to its ability to form a symbiotic relationship with nitrogen-fixing bacteria (Costa \& Durigan, 2010). This species forms dense groupings, produces a large amount of seeds and grows rapidly; characteristics that favor its invasive properties. Although Costa and Durigan (2010) classify Leucaena as a ruderal species, provided that it can proliferate in disturbed areas and make the establishment of mixed native species difficult, there are numerous studies that classify Leucaena as an invasive species. As consequence, it is listed as one of the planet's 100 most aggressive species (Scherer, 2005).

Our results, even though preliminary and in the short term, suggest that Senna and Cajanus could help competition and be useful to meet weed control needs (Figure 2). A similar study in riparian forests in the Lower São Francisco, in Sergipe state, found similar results; where planting seedlings could cost between US\$1200 and US $\$ 2500$ per hectare, while direct seeding would reduce costs to US\$912-1297 per hectare (Engel \& Parrotta, 2001). The restoration technique using inter-rows of diverse and green manure species by direct seeding seems to be an efficient and viable method to replace the needs for seedlings of the cover functional group. It can also help obtain a good vegetation cover in these degraded areas, at least when compared to conventional forest restoration planting over an evaluation period of up to 12 months after planting. In addition, said technique has the potential to be an economically more advantageous alternative, as it does not increase the number of maintenances required, but reduces the number of seedlings by almost half. 


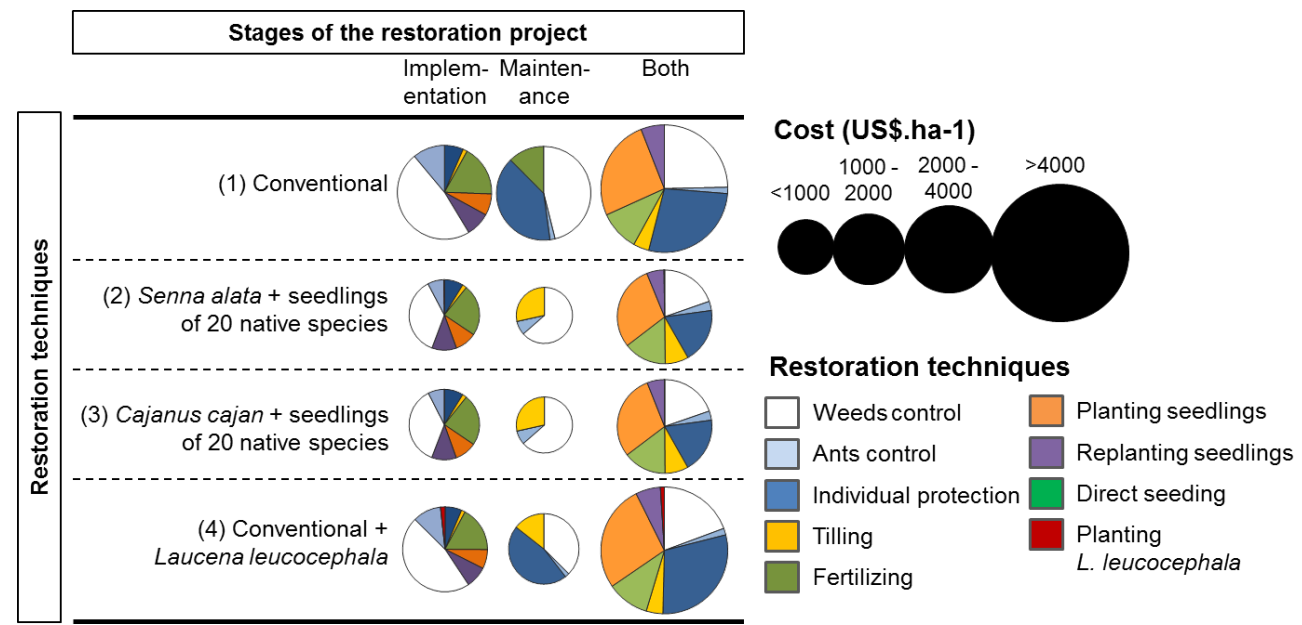

Figure 2. Cost of different activities during the implementation and maintenance phases of four restoration strategies in the Southeast Atlantic Forest in Brazil. Direct seeding is included in the implementation phase of the Senna and Cajanus strategies, but it is not visible in the figure due to its proportional low value ( US $\left.\$ 4 \mathrm{ha}^{-1}\right)$. (1) conventional planting seedlings of 20 native species $(2 \times 3 \mathrm{~m}$ spacing plants), (2) direct seeding of Senna alata among the seedlings of the 20 native species; (3) direct seeding of Cajanus cajan among seedlings of the 20 native species and; (4) direct seeding of Leucaena leucocephala in the inter-row of the 20 native species seedlings.

Considering that we only measured after the first 12 months, it is not possible to guarantee that these two strategies would be more cost-effective in terms of ecological benefits and economic costs. But the results suggest that direct seeding of green manure species may be a useful restoration strategy and may help to reduce weed competition in the region (César et al., 2013). Furthermore it may help to advance the regeneration in the first stages of the secondary succession (Bonilla-Moheno \& Holl, 2009). Particularly, Leucaena, despite being an exotic species, has been widely used for different economic purposes (Lamprecht, 1990), even in Brazil, due to its symbiotic relationship with nitrogen-fixing bacteria (Costa \& Durigan, 2010), fast soil covering, advance nucleation due to its large seed production, and growth rate. After one year, Leucaena trees were still very young; but after three years, they could improve soil conditions and contribute to the development of the native seedlings (Murgueitio et al., 2015). However, due to the short period of evaluation, it was not possible to verify its potential role as a strongly invasive plant.

\section{CONCLUSIONS}

Introducing green manure species by direct seeding may be a useful strategy to complement and eventually replace planting seedlings of other high-growth rate species in order to cover the soil surface rapidly. This approach may reduce some financial costs, in particularat the early stages of the projects.

\section{REFERENCES}

Beltrame, T. P., \& Rodrigues, E. (2007). Feijão guandu (Cajanus cajan (L.) Millsp.)na restauração de florestas tropicais. Semina: Ciências Agrárias, 28, 19-28.

Bonilla-Moheno, M., \& Holl, K. (2009). Direct seeding to restore tropical mature-forest species in areas of slash-and-burn agriculture. Restoration Ecology, 18, 438-445. http://dx.doi.org/10.1111/j.1526100X.2009.00580.X.

BIOFLORA-Técnologia de Restauração. (2013). Custos reflorestamentos (Comunicação oral). Piracicaba.

Campos-Filho, E. M., Sousa, O. L., \& Junqueira, R. G. P. (2013). Mechanized direct-seeding of native forests in Xingu, Central Brazil. Journal of Sustainable Forestry, 32, 702-727.

Ceccon, E., González, E. J., \& Martorell, C. (2016). Is direct seeding a biologically viable strategy for restoring forest ecosystems? Evidences from a meta-analysis. Land Degradation \& Development, 27, 511-520. 
César, R., Brancalion, P. H. S., Ribeiro Rodrigues, R., Medina Dos Santos Olivei Ra, A., \& Correa Alves, M. (2013). Does crotalaria (Crotalaria breviflora) or pumpkin (Cucurbita moschata) inter-row cultivation in restoration plantings control invasive grasses? Scientia Agrícola, 70, 268-273.

Costa, N. M. N., \& Durigan, G. (2010). Leucaena leucocephala (Lam.) de Wit (Fabaceae): invasora ou ruderal? Revista Árvore, 34(5), 825-833.

De Groot, R. S., Blignaut, J., Van Der Ploeg, S., Aronson, J., Elmqvist, T., \& Farley, J. (2013). Benefits of investing in ecosystem restoration. Conservation Biology, 27(6), 1286-1293. PMid:24112105.

Engel, V. L., \& Parrotta, J. A. (2001). An evaluation of direct seeding for reforestation of degraded lands in central Sao Paulo state, Brazil. Forest Ecology and Management, 152, 169-180.

Grossnickle, S., \& Ivetić, V. (2017). Direct seeding in reforestation: a field performance review. Reforesta, 4, 94-142.

Jørgensen, D. (2015). Ecological restoration as objective, target, and tool in international biodiversity policy. Ecology and Society, 20, 4.

Kimball, S., Lulow, M., Sorenson, Q., Balazs, K., Fang, Y. C., Davis, S. J., O'Connell, M., \& Huxman, M. E. (2015). Cost-effective ecological restoration. Restoration Ecology, 23, 800-810.

Lamprecht, H. (1990). Silvicultura nos trópicos: ecossistemas florestais e respectivas espécies arbóreaspossibilidades e métodos de aproveitamento sustentado (343 p.). Eschborn: GTZ.

Meli, P., Isernhagen, I., Brancalion, P. H. S., Isernhagen, E. C., Behling, M., \& Rodrigues, R. (2018). Optimizing seeding density of fast-growing native trees for restoring the Brazilian Atlantic Forest. Restoration Ecology, 26, 212-219.

Murgueitio, E., Calle, Z., Uribe, F., Calle, A., \& Solorio, B. (2015). Native trees and shrubs for the productive rehabilitation of tropical cattle ranching lands. Forest Ecology and Management, 261, 1654-1663.

Nave, A., Rodrigues, R., \& Gandolfi, S. (2009). Programa de adequação ambiental da Usina São Manoel (Usm) São Manoel, SP (230p.). Piracicaba: ESALQ, Departamento de Ciências Biológicas, Laboratório de Ecologia e Restauração Florestal.

Palma, A., \& Laurance, S. (2015). A review of the use of direct seeding and seedling plantings in restoration: what do we know and where should we go? Applied Vegetation Science, 18, 561-568.

Rodrigues, R., Gandolfi, S., Nave, A., Aronson, J., Barreto, T., Vidal, C., \& Brancalion, P. H. S. (2011). Largescale ecological restoration of high-diversity tropical forests in SE Brazil. Forest Ecology and Management, 261, 1605-1613.

Rodrigues, R., Lima, R. A., Gandolfi, S., \& Nave, A. (2009a). On the restoration of high diversity forests: 30 years of experiences in the Brazilian Atlantic Forest. Biological Conservation, 142, 1242-1251.

Rodrigues, R., Brancalion, P., \& Isernhagen, I. (2009b). Pacto pela restauração da Mata Atlântica: referencial dos conceitos e ações de restauração florestal (259p.). São Paulo: Instituto BioAtlântica.

Scherer, L. M. (2005). Allellopatic effects of aqueous extracts of leucena (Leucaena leucocephala Wit) leave and fruit on germination and root growth of canafístula (Peltophorum dubium Spreng). Semina. Ciências Biológicas e da Saúde, 26(2), 161-166.

Silva, R. R. P., Oliveira, D. R., Rocha, G. P. E., \& Vieira, D. L. M. (2015). Direct seeding of Brazilian savanna trees: effects of plant cover and fertilization on seedling establishment and growth. Restoration Ecology, 23, 393-401.

Uribe, F., Zuluaga, A. F., Valencia, L. M., Murgueitio, E., Zapata, A., \& Solarte, L. (2011). Establecimiento y manejo de sistemas silvopastoriles (78 p.). Bogotá: Banco Mundial, Fedegán, CIPAV, Fondo Accion.

Viani, R., Vidas, N., Pardi, M., Castro, D., Gusson, E., \& Brancalion, P. H. S. (2015). Animal-dispersed pioneer trees enhance the early regeneration in Atlantic Forest restoration plantations. Natureza \& Conservação, 13, 41-46.

Authors' contributions: DCVC: conceptualization, data curation, formal analysis, funding acquisition, investigation, methodology, project administration, writing - original draft, validation, RRR: conceptualization, supervision, validation, resources, supervision, validation, visualization, writing - review \& editing, PM: data curation, formal analysis, writing - review \& editing, PHSB: conceptualization, supervision, validation, supervision validation, writing - review \& editing, RRS: data curation, formal analysis, writing - review \& editing, HTZC: data curation, formal Analysis. 